\title{
KOMPONEN GIZI, AKTIVITAS ANTIOKSIDAN DAN KARAKTERISTIK SENSORI BUBUK FUNGSIONAL LABU KUNING (Cucurbita moschata) DAN TEMPE
}

\section{(Nutrient content, antioxidant activity and sensory characteristics of functional powder from pumpkin [Cucurbita moschata] and Tempeh)}

\author{
Dini Junita $^{1^{*}}$, Budi Setiawan ${ }^{2}$, Faisal Anwar ${ }^{2}$, Tjahja Muhandri ${ }^{3}$ \\ ${ }^{1}$ Program Studi Ilmu Gizi STIKes Baiturrahim Jambi, Jambi 36135 \\ ${ }^{2}$ Departemen Gizi Masyarakat, Fakultas Ekologi Manusia (FEMA), Institut Pertanian Bogor, Bogor 16680 \\ ${ }^{3}$ Departemen Ilmu dan Teknologi Pangan, Fakultas Teknologi Pertanian, Institut Pertanian Bogor, Bogor \\ 16680
}

\begin{abstract}
The aim of this research was to determine the nutrient content, antioxidant activity and the sensory characteristics of functional powder from pumpkin (Cucurbita moschata) and tempeh. The formula was consists of $15 \%$ pumpkinflesh powder, 35\% pumpkin seed powder, and $50 \%$ powder tempeh. The nutritional component was determined by proximate and spectrophotometric analysis, DPPH (2,2-diphenyl-1picrylhidrazyl) assay for antioxidant activity, and the sensory characteristics was analyzed by 39 semitrained panelists using 3 types of beverage i.e water, orange juice and milk. The results showed that the functional powder contained $6.84 \pm 0.09 \%$ moisture, $3.18 \pm 0.02 \%$ ash, $35.15 \pm 0.07 \%$ fat, $30.15 \pm 0.35 \%$ protein, $20.85 \pm 0.35 \%$ carbohydrate, $3.86 \pm 0.02 \%$ crude fiber, $308.85 \pm 0.55 \mathrm{ppm}$ total carotene, 515.00 ppb chromium, and $4.59 \%$ total sugar. Antioxidant activity of functional powder was 6765.88 ppm. According to the panelists, orange juice has the best sensory characteristics. This functional powder qualified for diabetic, futhermore investigate needed to improve the sensory characteristics and nutritional interactions.
\end{abstract}

Keywords: antioxidant activity, functional powder, nutrient content, sensory

\begin{abstract}
ABSTRAK
Penelitian bertujuan untuk mengetahui kandungan gizi, aktivitas antioksidan, dan karakteristik sensori formula bubuk fungsional berbahan labu kuning serta tempe. Formula yang digunakan terdiri atas $15 \%$ bubuk labu kuning, 35\% bubuk biji labu, 50\% bubuk tempe. Komponen gizi ditentukan berdasarkan dengan analisis proksimat dan spektrofotometri, aktivitas antioksidan metode DPPH (2,2-diphenyl-1picrylhidrazyl), serta karakteristik sensori formula dianalisis dengan bantuan 39 panelis semi terlatih menggunakan tiga jenis media minuman yaitu air putih, jus jeruk dan susu. Hasil penelitian menunjukkan bahwa bubuk fungsional mengandung 6,84 $\pm 0,09 \%$ kadar air, $3,18 \pm 0,02 \%$ kadar abu, $35,15 \pm 0,07 \%$ lemak, $30,15 \pm 0,35 \%$ protein, $20,85 \pm 0,35 \%$ karbohidrat, $3,86 \pm 0,02 \%$ serat kasar, $308,85 \pm 0,55 \mathrm{ppm}$ betakaroten, 515,00 ppb kromium, dan 4,59\% total gula. Aktivitas antioksidan bubuk sebesar 6765.88 ppm. Karakteristik sensori pada media jus jeruk lebih baik dari media lainnya. Bubuk fungsional ini dapat dimanfaatkan sebagai alternatif dalam manajemen diabetes, namun perlu peningkatan karakter sensori serta telaah interaksi gizi yang lebih mendalam.
\end{abstract}

Kata kunci: aktivitas antioksidan, bubuk fungsional, kandungan gizi, sensori

\section{PENDAHULUAN}

Pangan fungsional adalah pangan olahan yang mengandung satu atau lebih komponen pangan yang berdasarkan kajian ilmiah mempunyai fungsi fisiologis tertentu diluar fungsi dasarnya, terbukti tidak membahayakan dan bermanfaat bagi kesehatan (BPOM RI 2016). Menurut Kazeem dan Davies (2016), pangan fungsional adalah makanan dan minuman yang mampu mencegah, melindungi dan atau mengobati suatu penyakit dan juga memiliki nilai gizi yang baik.

Perkembangan intervensi gizi penyakit yang erat kaitannya dengan jenis makanan, perlu mengikuti perkembangan pangan. Saat ini muncul tren minuman bubuk (powder drink) yang terbuat dari berbagai buah, sayur, dan biji yang mengandung senyawa antioksidan dan protein whey (Suratno et al. 2014).

\footnotetext{
"Korespondensi: Telp: +6285266485585, Surel: dinijunita.dj.dj@gmail.com
} 
Junita dkk.

Labu kuning (Cucurbita moschata) merupakan pangan lokal yang memiliki bukti ilmiah mampu mengontrol gula darah. Beberapa penelitian pada tikus yang dibuat diabetes menunjukkan ekstrak labu kuning (Cucurbita moschata) memberikan efek hipoglikemik dan bertindak sebagai antidiabetes (Adams et al. 2011; Chang et al. 2014), ekstrak labu kuning (Cucurbita moschata) dan bubuk bijinya dapat memperbaiki sel islet pankreas dan produksi insulin (Makni et al. 2010; Jin et al. 2013). Menurut Glew et al. (2006) minyak biji labu kuning (Cucurbita moschata) juga mengandung mineral kromium yang diketahui berperan dalam metabolisme karbohidrat, dengan penyerapan kromium terbaik $<40 \mathrm{mcg}$ per sajian (Garcia et al. 2001).

Selaras dengan hal tersebut kedelai dan berbagai olahan fermentasi kedelai telah lama diketahui dapat mengontrol kadar gula darah, mengurangi resistensi insulin serta meningkatkan sensitivitas insulin (Park et al. 2012; Matsukawa et al. 2015). Kandungan flavonoid isoflavon pada tempe khususnya daidzen dan genistein sangat bermanfaat bagi tubuh (Esteves et al. 2011). Tempe merupakan sumber protein yang baik, yang dibutuhkan untuk regenerasi sel.

Pengolahan daging buah dan biji labu kuning serta tepung tempe menjadi minuman fungsional dalam bentuk serbuk (bubuk) dirasa cukup potensial, agar manfaatnya dapat dinikmati lebih praktis. Oleh karena itu, sebagai landasan manfaatnya, komponen zat gizi, kemampuan antioksidan, serta karakteristik sensori campuran bubuk ini perlu diteliti.

\section{METODE}

\section{Desain, tempat, dan waktu}

Penelitian ini merupakan penelitian eksperimental, dilaksanakan pada bulan Desember 2016 sampai dengan Juni 2017. Pengujian dilakukan di Laboratorium Saraswanti Indo Genetech (SIG) Bogor, Laboratorium Balai Besar Industri Agro (BBIA) Bogor, Laboratorium Biofarmaka IPB dan Laboratorium Organoleptik Gizi Masyarakat IPB.

\section{Bahan dan alat}

Bahan yang digunakan untuk campuran bubuk kering yaitu $15 \%$ bubuk labu kuning, 35\% bubuk biji labu dan $50 \%$ bubuk tempe diketahui mengandung total gula 4,59\% dan kromium 50,15 $\mathrm{mcg} / 100 \mathrm{~g}$. Bahan kimia yang digunakan yaitu 2,2-diphenyl-1-picrylhidrazyl (DPPH), vitamin $\mathrm{C}$, asam asetat, dan $\mathrm{CH} 3 \mathrm{COONa}$, dipilih dari merek Sigma-Aldrich (St. Louis, MO) dan Merck (Darmstadt, Germany), dengan mutu minimal pro-analysis dan pure diperoleh dari toko kimia. Bahan kimia lain yang biasa digunakan dalam analisa proksimat. Media yang digunakan dalam pengujian sensori yaitu air mineral, jus jeruk dan susu cair plain, merupakan produk komersial top brand.

Analisis kandungan gizi menggunakan alat uji proksimat. Alat yang digunakan dalam analisis antioksidan adalah spektrofotometer (Specord 210, model analytikjena). Analisis kandungan kromium dengan Atomic Absorbance Spectrophotometer (ICP OES Agilent type 720 detector $C C D)$, serta total gula dengan High Performance Liquid Chromatography (Waters 2695 - Alliance Model, Milford, USA). Pengujian organoleptik menggunakan kuesioner sensori dan alat saji.

\section{Tahapan penelitian}

Analisis fisikokimia bubuk fungsional.

Komponen gizi diketahui melalui analisis proksimat meliputi analisis air (SNI.01- 2891-1992, butir 5.1), kadar abu (SNI.01- 2891-1992, butir 6.1), kadar protein (SNI.01- 2891-1992, butir 7.1), kadar lemak (SNI.01-2891-1992, butir 8.1), karbohidrat (metode by difference), serat kasar (SNI.01- 2891-1992, butir 11). Komponen total karoten dan kromium menggunakan metode spektrofotometri, total gula dengan metode Luff schoorl.

Analisis aktivitas antioksidan. Pengujian ini dilihat berdasarkan kemampuan antioksidan dalam menangkal radikal DPPH merujuk pada penelitian Salazar et al. (2009) dan Wu et al. (2014). Mekanisme penangkalan ditentukan oleh penghilangan warna dari radikal DPPH. Sampel uji dicampur dengan etanol $(1 \mathrm{mg} / \mathrm{ml})$ pada beberapa konsentrasi etanol berbeda. Selain itu juga disiapkan larutan DPPH yang terdiri dari $1,3 \mathrm{~g}$ DPPH dicampur etanol pro analisis hingga $25 \mathrm{ml}$. Sebanyak $0,5 \mathrm{ml}$ larutan sampel dipipet untuk dimasukkan ke microplate lalu penambahan $0,5 \mathrm{ml}$ larutan DPPH. Setelah itu campuran diinkubasi pada suhu ruang dan gelap selama 30 menit. Kemudian absorbansi diukur dengan spektofometer pada panjang gelombang $517 \mathrm{~nm}$. Demikian pula pada blanko atau kontrol. Kontrol yang digunakan dalam penelitian ini adalah Vitamin C. Aktivitas antioksidan dinyatakan sebagai persentase dihitung sesuai dengan rumus berikut.

Aktivitas antioksidan $(\%)=\frac{\text { Absorbansi kontrol }- \text { Absorbansi sampel }}{\text { Absorbansi kontrol }} \times 100 \%$

Absorbansi kontrol adalah absorbansi larutan DPPH ditambah vitamin C dan absorbansi sampel adalah absorbansi larutan DPPH setelah penambahan sampel. Nilai konsentrasi peng-

J. Gizi Pangan, Volume 12, Nomor 2, Juli 2017 
hambatan aktivitas radikal bebas seba-nyak 50\% $\left(\mathrm{IC}_{50}\right)$ dihitung dari persamaan grafik persentase penghambatan.

Analisis karakteristik sensori. Pengujian karakteristik sensori dilakukan menggunakan tiga media minuman yaitu air putih, jus jeruk, dan susu cair. Media minuman merupakan produk komersial top brand. Pengujian sensori terdiri atas hedonik dan mutu hedonik meliputi atribut warna, aroma, tekstur dan rasa metode skala 1-9 dilakukan oleh 39 orang panelis semi terlatih yang merupakan mahasiswa gizi IPB (Usha et al. 2010). Skor mutu hedonik dikelompokkan de-ngan nilai tengah sebagai batas kecendrungan, sedangkan skor hedonik dikelompokkan menjadi tiga yaitu $\leq 3$ tidak suka, 3-6 agak suka, dan $\geq 6$ suka (Yuni et al. 2016). Penilaian dilakukan pada media dengan dan tanpa penambahan bubuk fungsional. Setiap $20 \mathrm{~g}$ bubuk dicampur dengan $150 \mathrm{ml}$ media minum, dan disajikan sebanyak 20 $\mathrm{ml}$.

\section{Pengolahan dan analisis data}

Pengolahan data dilakukan dengan menggunakan Microsoft Excel 2007 dan IBM SPSS 16. Data hasil kandungan zat gizi produk, dianalisis secara deskriptif berdasarkan nilai ratarata, sedangkan nilai $\mathrm{IC}_{50}$ aktivitas antioksidan dihitung berdasarkan persamaan grafik linear. Untuk mengetahui pengaruh penerimaan sebelum dan setelah penambahan bubuk fungsional pada media minum, digunakan uji paired t-test dan Wilcoxon $(\alpha=0,05)$. Penentuan media dengan penerimaan terbaik digunakan metode perbandingan eksponensial.

\section{HASIL DAN PEMBAHASAN}

\section{Kandungan gizi bubuk fungsional}

Tabel 1 menunjukkan bahwa nilai kadar air bubuk fungsional adalah $6,84 \pm 0,09 \%$. Nilai ini telah memenuhi standar mutu kadar air minuman bubuk yang ditetapkan dari SNI 01-43241996, yakni kurang dari 10\% (Mawardi et al. 2016). Kadar air pen-ting sebagai indikator daya simpan produk pa-ngan, semakin tinggi kadar air semakin rendah masa simpan dan semakin butuh perlakuan khusus dalam penyimpanan.

Kandungan protein formula bubuk fungsional lebih tinggi dari bubuk labu kuning dan biji labu kuning namun lebih rendah dari nilai protein tepung tempe. Kandungan protein dipengaruhi oleh komposisi bahan campuran dan proses pengolahan. Tempe sebagai proporsi terbesar dalam campuran bubuk fungsional memiliki kandungan protein terbesar dibanding kedua bahan lainnya. Menurut Viguiliouk (2015) konsumsi sumber protein nabati dapat memperbaiki kontrol glikemik pada individu dengan diabetes.

Kandungan lemak total pada formula bubuk fungsional lebih tinggi daripada bubuk labu kuning dan tempe, namun masih lebih kecil dari bubuk biji labu kuning. Lemak nabati yang berasal dari tempe biji labu kuning dan kacang kedelai merupakan lemak tak jenuh yang baik untuk kesehatan. Menurut Morrison et al. (2015) dan Zhao et al. (2015) minyak biji labu kuning dapat memperbaiki dislipidemia dengan menurunkan kadar kolesterol LDL dan trigliserida, menipiskan aterosklerosis dan memberi efek antiinflamasi.

Karbohidrat total pada formula bubuk jauh lebih kecil dibandingkan bubuk labu kuning, namun masih lebih tinggi dari pada bubuk biji labu dan tempe. Hasil uji gula total sebesar 4,59\% menyatakan bubuk ini memenuhi syarat minuman rendah gula maksimal 5\% (BPOM 2016).

\section{Aktivitas antioksidan bubuk fungsional}

Penentuan aktivitas antioksidan bubuk fungsional dilakukan menurut metode DPPH (2,2-diphenyl-1-picrylhidrazyl). DPPH meru-

Tabel 1. Kandungan gizi bubuk labu kuning, biji labu kuning, tempe, dan bubuk fungsional

\begin{tabular}{|c|c|c|c|c|}
\hline Parameter & Bubuk labu kuning $^{\mathrm{a}}$ & Bubuk biji labu kuning $^{\mathrm{b}}$ & Bubuk tempe $^{c}$ & Bubuk fungsional $^{*}$ \\
\hline Kadar air (\%) & $6,37 \pm 0,86$ & $2,54 \pm 0,02$ & $3,95 \pm 0,37$ & $6,84 \pm 0,09$ \\
\hline Kadar abu (\%) & $5,39 \pm 0,97$ & $3,21 \pm 0,16$ & $1,48 \pm 0,24$ & $3,18 \pm 0,02$ \\
\hline Protein $(\%)$ & $5,06 \pm 0,20$ & $36,47 \pm 0,48$ & $49,88 \pm 0,46$ & $35,15 \pm 0,07$ \\
\hline Lemak (\%) & $1,16 \pm 0,29$ & $51,01 \pm 0,28$ & $29,06 \pm 0,30$ & $30,15 \pm 0,35$ \\
\hline Karbohidrat (\%) & $82,02 \pm 1,38$ & $6,77 \pm 1,33$ & $14,49 \pm 0,34$ & $20,85 \pm 0,35$ \\
\hline Serat kasar (\%) & $9,51 \pm 2,39$ & $4,43 \pm 0,59$ & $5,08 \pm 0,43$ & $3,86 \pm 0,02$ \\
\hline Total Karoten (ppm) & $2147,2^{\mathrm{d}}$ & td & td & $308,85 \pm 0,55$ \\
\hline Kromium (ppb) & $639,35^{*}$ & $491,33^{*}$ & $465,15^{*}$ & 515,00 \\
\hline $\begin{array}{l}\text { Total gula (\%) } \\
\text { "Hasil analisis: aTrisnaw: }\end{array}$ & $\frac{24,3^{*}}{\text { et al. }(2014) ;{ }^{\circ} \mathrm{El} \text { Adz }}$ & $\frac{1,15^{*}}{\text { an Taha (2001); }{ }^{\mathrm{C}} \text { Mursyid }}$ & $\begin{array}{c}0,63 * \\
\text { 14); ‘Manasika c }\end{array}$ & $\begin{array}{c}4,59 \\
\text { Widjanarko (2015) }\end{array}$ \\
\hline
\end{tabular}


pakan radikal bebas yang stabil pada suhu kamar. Interaksi antioksidan dengan DPPH baik secara transfer elektron atau radikal hidrogen pada DPPH akan menetralkan karakter radikal bebas dari DPPH.

Berdasarkan grafik aktivitas antioksidan (Gambar 1), diketahui bahwa bubuk fungsional memiliki kemampuan dalam menghambat radikal bebas DPPH, namun persentase hambatannya masih rendah dibandingkan vitamin $C$ yaitu rata-rata di bawah 3,5\%. Kedua persamaan linear yang dihasilkan dari tiap titik persen penghambatan menghasilkan rata-rata nilai $\mathrm{IC}_{50}$ bubuk fungsional sebesar $6765,88 \mathrm{ppm}$. Nilai $\mathrm{IC}_{50}$ menyatakan kemampuan pangan dalam menangkal $50 \%$ senyawa radikal, semakin rendah nilai $\mathrm{IC}_{50}$ maka semakin tinggi kemampuan bahan sebagai antioksidan (Topal et al. 2015).

Menurut Rustina et al. 2016, suatu zat dikatakan memiliki aktivitas antioksidan lemah jika nilai $\mathrm{IC}_{50}$ dari senyawa tersebut lebih dari $150 \mathrm{mcg} / \mathrm{ml}$ atau setara dengan $150 \mathrm{ppm}$. Meskipun termasuk kategori lemah kemampuan antioksidan bubuk fungsional ini lebih tinggi dari bubuk labu kuning dengan nilai $\mathrm{IC}_{50}$ sebesar 9.900 ppm (Trisnawati et al. 2014) dan serbuk biji labu kuning dengan $\mathrm{IC}_{50} 114.000$ ppm (Pabesak et al.

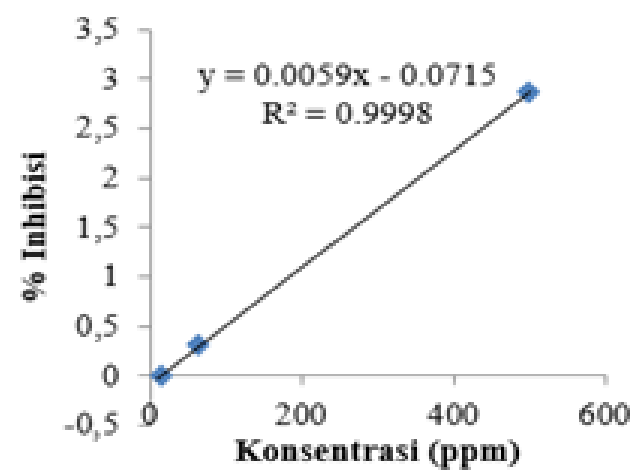

(a)

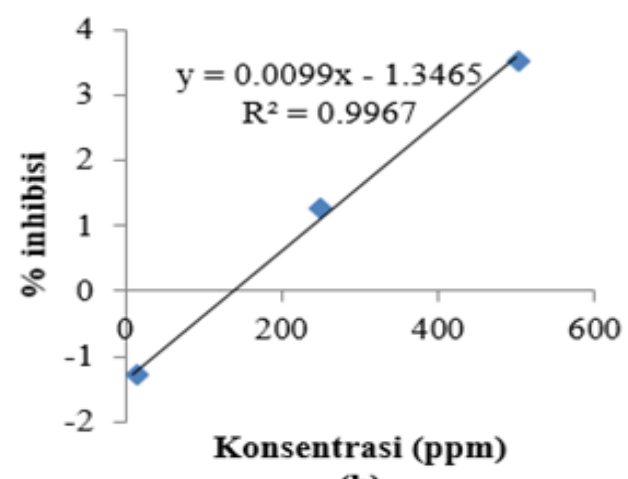

(b)

Gambar 1. Grafik aktivitas antioksidan bubuk fungsional (a) ulangan pertama dan (b) ulangan kedua.
2013), namun lebih rendah dari antioksidan tepung tempe dengan $\mathrm{IC}_{50} 4.049,6 \mathrm{ppm}$ (Mursyid 2014).

Komponen fitokimia sebagai antioksidan berperan melawan stres oksidatif sehingga mencegah memburuknya penyakit kronis pada manusia. Diet seimbang yang diperkaya dengan komponen bioaktif pada makanan tinggi antioksidan, berpotensi memberikan perlindungan terhadap kerusakan metabolik (Sarkar \& Shetty 2014). Senyawa antioksidan juga dapat mencegah perkembangan komplikasi diabetes jangka panjang termasuk penyakit kardiovaskular, neuropati, nefropati, dan retinopati (Bahadoran et al. 2013).

\section{Karakteristik sensori bubuk fungsional}

Pengujian sensori dilakukan untuk mengetahui respon atau kesan yang diperoleh panca indera manusia terhadap suatu rangsangan yang ditimbulkan oleh suatu produk. Karakteristik sensori yang dilihat dari bubuk fungsional sebagai minuman meliputi mutu hedonik dan hedonik.

Mutu hedonik terdiri atas atribut warna dilihat dari intensitas warna, atribut aroma dilihat dari keberadaan aroma labu kuning, aroma tempe, aroma langu, atribut tekstur dilihat dari tingkat kekentalan dan kehalusan cairan, atribut rasa dilihat dari tingkat kemanisan, tingkat rasa pahit dan keberadaan after taste.

Tabel 2 menunjukkan bahwa terdapat perbedaan subjek pada media dengan dan tanpa penambahan bubuk fungsio-nal, beberapa atribut menunjukkan kenaikan dan beberapa atribut sebaliknya. Uji berpasangan terhadap kondisi penerimaan sensori berbagai media tanpa dan dengan bubuk fungsional menunjukkan bahwa hampir seluruh atribut di ketiga media berbeda secara nyata. Signifikan positif pada media air putih yaitu penambahan bubuk meningkatkan rasa manis dan tekstur kental pada air putih. Beberapa atribut yang tidak signifikan berbeda yaitu aroma labu, rasa manis dan after taste pada media jus jeruk, serta pada media susu yaitu atribut intensitas warna dan kekentalan.

Hasil tersebut menjelaskan bahwa penggunaan media jus jeruk dalam konsumsi bubuk fungsional ini mampu menutupi atribut aroma, rasa, dan after taste bubuk fungsional dengan lebih baik. Penggunaan media atau campuran buah sebagai penambah citarasa minuman dapat membantu mengurangi kesan langu dari bahan minuman (Triastuti et al. 2013). Selain itu, nilai kekentalan pada atribut tekstur media jus jeruk mengalami kenaikan yang signifikan. Intensitas warna dan kekentalan pada media susu tanpa dan 
Tabel 2. Atribut mutu hedonik pada media minum tanpa dan dengan penambahan bubuk fungsional

\begin{tabular}{|c|c|c|c|}
\hline Atribut mutu hedonik & $\begin{array}{c}\text { Tanpa bubuk } \\
\text { (Rataan } \pm \text { sd) }\end{array}$ & $\begin{array}{c}\text { Dengan bubuk } \\
\text { (Rataan } \pm \text { sd })\end{array}$ & $\mathrm{p}$ \\
\hline \multicolumn{4}{|l|}{ Air putih } \\
\hline Intensitas warna & $7,40 \pm 2,43$ & $2,55 \pm 1,89$ & $0,000 * *$ \\
\hline Aroma labu & $0,43 \pm 0,78$ & $2,12 \pm 2,23$ & $0,000^{* *}$ \\
\hline Aroma tempe & $0,43 \pm 0,74$ & $5,52 \pm 2,37$ & $0,000 * *$ \\
\hline Aroma langu & $0,42 \pm 0,77$ & $5,53 \pm 2,44$ & $0,000 * *$ \\
\hline Kekentalan & $0,29 \pm 0,58$ & $4,14 \pm 2,23$ & $0,000 * *$ \\
\hline Kehalusan & $7,18 \pm 3,15$ & $2,37 \pm 1,28$ & $0,000 * *$ \\
\hline Rasa manis & $0,87 \pm 1,62$ & $1,45 \pm 2,05$ & $0,050^{* *}$ \\
\hline Rasa pahit & $0,55 \pm 1,29$ & $5,04 \pm 2,80$ & $0,000^{* *}$ \\
\hline After taste & $0,60 \pm 1,40$ & $6,02 \pm 2,31$ & $0,000^{* *}$ \\
\hline \multicolumn{4}{|l|}{ Jus jeruk } \\
\hline Intensitas warna & $7,32 \pm 1,31$ & $4,68 \pm 2,36$ & $0,000^{*}$ \\
\hline Aroma labu & $2,30 \pm 2,62$ & $2,55 \pm 2,22$ & 0,318 \\
\hline Aroma tempe & $0,92 \pm 1,15$ & $1,92 \pm 1,94$ & $0,000^{* *}$ \\
\hline Aroma langu & $1,38 \pm 1,71$ & $2,32 \pm 2,03$ & $0,001 * *$ \\
\hline Kekentalan & $2,57 \pm 1,82$ & $4,14 \pm 2,00$ & $0,000^{*}$ \\
\hline Kehalusan & $5,96 \pm 2,07$ & $2,61 \pm 1,53$ & $0,000^{*}$ \\
\hline Rasa manis & $4,65 \pm 2,29$ & $5,11 \pm 1,58$ & 0,198 \\
\hline Rasa pahit & $1,90 \pm 2,24$ & $2,65 \pm 2,06$ & $0,013 * *$ \\
\hline After taste & $4,49 \pm 5,55$ & $4,31 \pm 2,46$ & 0,342 \\
\hline \multicolumn{4}{|l|}{ Susu } \\
\hline Intensitas warna & $4,07 \pm 2,99$ & $3,58 \pm 2,14$ & 0,260 \\
\hline Aroma labu & $0,74 \pm 1,25$ & $1,64 \pm 1,75$ & $0,000^{* *}$ \\
\hline Aroma tempe & $0,67 \pm 1,16$ & $3,10 \pm 2,51$ & $0,000^{* *}$ \\
\hline Aroma langu & $1,09 \pm 1,70$ & $3,24 \pm 2,47$ & $0,000^{* *}$ \\
\hline Kekentalan & $3,47 \pm 2,26$ & $4,14 \pm 2,26$ & 0,100 \\
\hline Kehalusan & $6,84 \pm 2,12$ & $3,93 \pm 2,02$ & $0,000^{* *}$ \\
\hline Rasa manis & $3,30 \pm 2,16$ & $2,24 \pm 1,90$ & $0,006^{*}$ \\
\hline Rasa pahit & $0,97 \pm 1,50$ & $4,19 \pm 2,82$ & $0,000^{* *}$ \\
\hline After taste & $2,83 \pm 2,66$ & $5,08 \pm 2,80$ & $0,000^{* *}$ \\
\hline
\end{tabular}

*paired t-test signifikan pada $\mathrm{p}<0,05$; **Wilcoxon signifikan pada $\mathrm{p}<0,05$; Ket: Skor $<4,5$ mutu cenderung lemah, skor $\geq 4,5$ mutu cenderung kuat

dengan penambahan tidak berbeda signifikan, menjelaskan bahwa bubuk fungsional ini tidak signifikan merubah warna dan kekentalan pada susu.

Penilaian hedonik pada produk menggambarkan persepsi kesukaan (hedonik) panelis dalam menentukan media yang paling diterima. Atribut warna pada uji hedonik menggambarkan kesukaan panelis terhadap warna yang muncul dari pencampuran antara warna media dengan warna bubuk fungsional. Gambar 2 menunjukan hasil penilaian panelis terhadap atribut warna untuk ketiga media adalah agak suka, dengan nilai kesukaan tertinggi adalah pada jus jeruk. Atribut warna dipengaruhi oleh komponen pembentuk warna dari bubuk dan media yang digunakan. Proporsi komponen labu kuning yang kecil dibandingkan dua komponen lainnya menyebabkan warna kuning tidak begitu menonjol, selain itu warna keruh pada bubuk mengurangi kecerahan warna minuman sehingga penilaian panelis terhadap intensitas warna media dengan penambahan bubuk justru menurun dibanding sebelumnya (Malinda et al. 2013).

Media air putih adalah yang paling tidak disukai untuk atribut aroma, sedangkan nilai 
aroma tertinggi dihasilkan oleh media jus jeruk. Hal ini disebabkan oleh mutu aroma tempe dan langu yang kuat pada media air putih dan susu. Sebanyak $85 \%$ panelis yang tidak menyukai aroma media air dan $62,5 \%$ dari panelis yang tidak suka aroma media susu menyatakan aroma langu

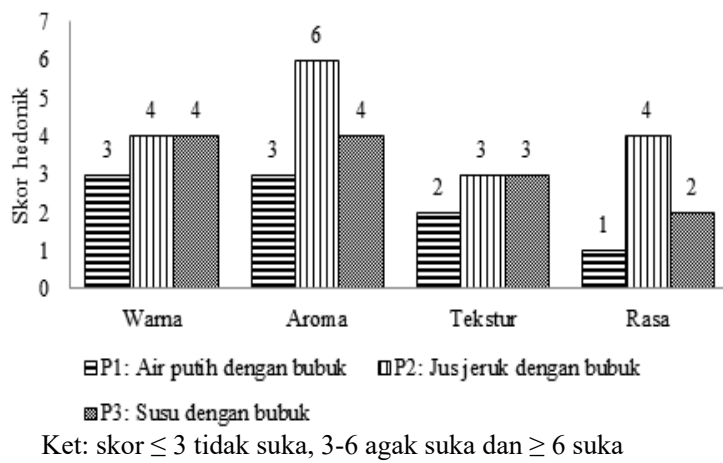

Gambar 2. Grafik hasil uji hedonik pada ketiga media

cenderung kuat. Sebaliknya pada media jeruk kesan aroma labu, tempe, dan langu cenderung lemah sehingga meningkatkan kesukaan terhadap atribut aroma. Aroma langu berasal dari senyawa volatil (Lee et al. 2013) dan terpenoid yaitu metabolit sekunder dalam terkandung pada kacang kedelai (Liu et al. 2014).

Pada atribut tekstur, rata-rata panelis tidak menyukai tekstur pada media air putih dan jus jeruk, sedangkan pada media susu tekstur agak disukai. Panelis menyatakan tekstur berpasir dan bertepung paling dominan terasa pada media air putih sedangkan tekstur berminyak dominan terasa pada media susu, namun kesan berminyak tidak mengganggu tingkat kesukaan panelis terlihat dari nilai tekstur pada media susu lebih disukai. Tekstur kasar, kesan berpasir dan bertepung disebabkan oleh komponen yang tidak larut, sedangkan kesan berminyak timbul akibat kandungan lemak pada media susu dan biji labu kuning. Kesan tekstur kasar berkurang pada media susu karena bubuk dan susu memiliki kandungan gizi yang mirip yaitu adanya kandungan protein dan lemak. Suatu bahan akan mudah larut dalam bahan yang sejenis karena polaritas yang sama membuatnya lebih mudah menyatu. Selain itu pada kedelai terdapat kandungan terpenoid yang lebih bersifat non polar sehingga cenderung lebih mudah larut dalam pelarut non polar yaitu lemak (Septiana \& Asnani 2012).

Atribut rasa, panelis agak menyukai rasa jus jeruk sebagai media konsumsi bubuk fungsional, namun tidak menyukai kedua media lainnya. Flavor merupakan gabungan aroma dan rasa, sehingga aroma yang segar akan memberikan kenikmatan rasa yang lebih baik (Shofiati et al. 2014). Selain itu, adanya after taste menyebabkan rendahnya penerimaan rasa. Rasa jus jeruk yang lebih manis dengan aroma khas jeruk yang segar dapat menutupi after taste pada minuman (Triastuti et al. 2013).

Berdasarkan hasil penilaian uji hedonik, diketahui bahwa penerimaan panelis pada ketiga media berada dalam kategori tidak suka hingga agak suka. Penentuan media terbaik menggunakan metode perbandingan eksponensial yaitu setiap atribut mutu hedonik dan hedonik di ranking, kemudian ranking dijumlahkan. Media dengan penerimaan paling tinggi adalah yang memiliki jumlah rangking terkecil yaitu jus jeruk.

\section{KESIMPULAN}

Bubuk fungsional memiliki kandungan gizi yang lebih lengkap, memenuhi syarat rendah gula dan mengandung kromium sehingga dapat dimanfaatkan dalam manajemen diabetes. Terkait bioavailabilitas kromium sebaiknya bubuk fungsional diminum tidak lebih dari 80 $\mathrm{g} /$ kali konsumsi. Aktivitas antioksidan bubuk fungsional dalam kategori lemah namun lebih baik dari aktivitas antioksidan bubuk labu dan biji labu tanpa pencampuran. Karakteristik sensori bubuk fungsional untuk atribut mutu dinilai masih kurang, intensitas warna kurang cerah, aroma langu, tekstur kasar serta keberadaan after taste pahit menjadi poin penting untuk perbaikan kedepannya. Penggunaan media jus jeruk mampu memperbaiki nilai kesukaan terhadap bubuk fungsional, namun perlu di telaah lebih dalam termasuk kaitannya dengan interaksi zat gizi.

\section{UCAPAN TERIMA KASIH}

Penulis mengucapkan terima kasih kepada STIKes Baiturrahim Jambi yang telah membiayai sebagian penelitian ini.

\section{DAFTAR PUSTAKA}

Adams GG, Imran S, Wang S, Mohammad A, Kök MS, Gray DA, Channell GA, Morris GA, Harding SE. 2011. The hypoglycaemic effect of pumpkins as antidiabetic and functional medicines. J foodres (44):862867.doi:10.1016/j.foodres.2011.03.016.

[BPOM RI]. Badan Pengawasan Obat dan Makanan RI. 2016. Pengawasan Klaim dalam Label dan Iklan Pangan Olahan. Nomor 13 Tahun 2016. Jakarta: BPOM RI. Bahadoran Z, Mirmiran P, Azizi F. 2013. Dietary polyphenols as potential nutraceuticals in 
management of diabetes: a review. J DMD (12)43:1-9. http://www.jdmdonline.-com/ content/12/1/43.

Chang CI, Hsu CM, Li TS, Huang SD, Lin CC, Yen CH, Chou CH, Cheng HL. 2014. Constituents of the stem of Cucurbita moschata exhibit antidiabetic activities through multiple mechanisms. J JFF 6(10):260-273. doi:10.1016/j.jff.2014.06.017.

El Adawi TA, Taha KM. 2001. Characteristics and composition of watermelon, pumpkin, and paprika seed oils and flours. J Agric Food Chem. 49(3):1253-1259.

Esteves EA, Bressan J, Costa NMB, Martino HSD, Donkin SS, Story JA. 2011. Modified soybean affects cholesterol metabolism in rats similarly to a commercial cultivar. $\mathrm{J}$ Med Food 14(11):1363-1369. doi:10.1089/ jmf.2010.0160.

Garcia E, Cabrera C, Lorenzo ML, LÓpez MC, SÁnchez J. 2001. Estimation of chromium bioavailability from the diet by an in vitro method. Food Addit Contam 18(7):601606. doi:10.1080/02652030117232.

Glew RH, Glew RS, Chuang LT, Huang YS, Millson M, Constans D, Vanderjagt DL. 2006. Amino acid, mineral and fatty acid content of pumpkin seeds (cucurbita spp) and cyperus esculentus nuts in The Republic of Niger. Plant Foods for Human Nutrition 61(2):49-54.doi: 10.1007/s11130-0060010-Z.

Jin H, Zhang YJ, Jiang JX, Zhu LY, Chen P, Li J, Yao HY. 2013. Studies on the extraction of pumpkin components and their biological effects on blood glucose of diabetic mice. Journal of food and drug analysis. 21(2): 184-189. doi: 10.1016/j.jfda.2013.05.009.

Kazeem MI, Davies, TC. 2016. Anti-diabetic functional foods as sources of insulin secreting, insulin sensitizing and insulin mimetic agents. Journal of Functional Foods. 20:122-138.doi:10.1016/j.jff.2015.10.013.

Lee J, Chambers DH, Chambers E, Adhikari K, dan Yoon Y. 2013. Volatile aroma compounds in various breewed green teas. Molecules 18:10024-10041.

Liu J, Huang F, Wang X, Zhang M, Zheng R, Wang J, Yua D. 2014. Genome-wide analysis of terpene synthases in soybean: functional characterization of GmTPS3. Gene 544:8392. doi: 10.1016/j.gene.2014.04.046.

Makni M, Sefi M, Fetoui H, Garoui EM, Gargouri NK, Boudawara T, Zeghal N. 2010. Flax and pumpkin seeds mixture ameliorates diabetic nephropathy in rats. Food Chem Toxicol 48(8-9):2407-2412. doi: 10.1016/j. fct.2010.05.079.

Malinda AP, Katri RB, Rachmawanti D, Riyadi NH. 2013. Kajian penambahan tepung millet dan tepung ubi jalar ungu (ipomoea batatas sebagai substitusi tepung terigu pada pembuatan flake. Jurnal Teknosains Pangan 2(1).

Manasika A, Widjanarko SB. 2015. Ekstraksi pigmen karotenoid labu kabocha menggunakan metode ultrasonik (kajian rasio bahan: pelarut dan lama ekstraksi). Jurnal Pangan dan Agroindustri 3(3):928-938.

Matsukawa T, Inaguma T, Han J, Villareal MO, Isoda H. 2015. Cyanidin-3-glucoside derived from black soybeans ameliorate type 2 diabetes through the induction of differentiation of preadipocytes into smaller and insulin-sensitive adipocytes. J Nutr Biochem 26(8):860-867. doi:10.1016/j.jnutbio.2015.03.006.

Mawardi YSA, Pramono YB, Setiani BE. 2016. Kadar air, tanin, warna dan aroma offflavour minuman fungsional daun sirsak (annona muricata) dengan berbagai konsentrasi jahe (zingiber Officinale). Jurnal Aplikasi Teknologi Pangan 5(3):94-98. http://dx.doi.org/10.17728/jatp.179.

Morrison MC, Mulder P, Stavro PM, Suárez M, Arola-Arnal A, van Duyvenvoorde W. 2015. Replacement of dietary saturated fat by PUFA-rich pumpkin seed oil attenuates non-alcoholic fatty liver disease and atherosclerosis development, with additional health effects of virgin over refined oil. PLoS ONE 10(9):e0139196. doi:10.1371/ journal. pone.0139196

Mursyid. 2014. Kandungan zat gizi dan nilai gizi protein tepung tempe kedelai lokal dan impor serta aktivitas antioksidannya [tesis]. Bogor: Ilmu pangan, Institut Pertanian Bogor.

Pabesak RV, Dewi L, Lestario LN. 2013. Aktivitas antioksidan dan fenolik total pada tempe dengan penambahan biji labu kuning (Cucurbita moschata ex poir). Seminar Nasional X Pendidikan Biologi FKIP UNS.

Park S, Kim DS, Kim JH, Kim JS, Kim HJ. 2012. Glyceollin-containing fermented soybeans improve glucose homeostasis in diabetic mice. Nutrition 28(2):204-211. doi:10.1016/j.nut.2011.05.016.

Rustina. 2016. Uji aktivitas antioksidan dan antibakteri ekstrak etil asetat biji labu kuning 
Junita dkk.

(Cucurbita moschata duch Poir.) [Skripsi]. Yogyakarta: Universitas Muhammadiyah Yogyakarta.

Salazar AR, P'erez-L'opez LA, L'opez-Arroyo J, Alan'1s-Garza BA, and de Torres NW. 2009. Antimicrobial and Antioxidant Activities of Plants from Northeast of Mexico. Evid Based Complement Alternat Med. 2011:536139. doi:10.1093/ecam/nep127.

Sarkar D, Shetty K. 2014. Aging, chapter 27: Metabolic Mobilization Strategies to Enhance the Use of Plant-Based Dietary Antioxidants for the Management of Type 2 Diabetes. Department of Plant Science. Loftsgard Hall, NDSU, Fargo,ND 289296. doi:10.1016/B978-0-12-4059337.00027-5.

Septiana AT, Asnani A. 2012. Kajian sifat fisikokimia ekstrak rumput laut coklat Sargassum duplicatum menggunakan berbagai pelarut dan metode ekstraksi. AGROINTEK. 6(1):22-28.

Shofiati A, Andriani MAM, Anam C. 2014. Kajian kapasitas antioksidan dan penerimaan sensoris teh celup kulit buah naga (pitaya fruit) dengan penambahan kulit jeruk lemon dan stevia. Teknosains Pangan 3(2):513.

[SNI] Standar Nasional Indonesia. 1992. Cara uji makanan dan minuman. Jakarta: Badan Standarisasi Nasional.

Suratno YD, Palupi NS, Astawan M. 2014. Pola konsumsi pangan fungsional dan formulasi minuman fungsional instan berbasis antioksidan. Jurnal Mutu Pangan 1(1):56-64. ISSN 2355-5017.

Topal F, Nar M, Gocer H, Kalin P, Kocyigit UM, Gülçin I, Alwasel SH. 2015. Antioxidant activity of taxifolin: an activity-structure relationship. J Enzyme Inhib Med Chem
31(4):674-683. doi:10.3109/14756366.20 15.1057723

Triastuti I, Nurainy F, dan Nawansih O. 2013. Kajian produksi minuman campuran sari wortel dengan berbagai buah. Jurnal Teknologi Industri dan Hasil Pertanian 18(2): 101-113.

Trisnawati W, Suter K, Suastika K, Putra NK. 2014. Pengaruh Metode Pengeringan Terhadap Kandungan Antioksidan, Serat Pangan dan Komposisi Gizi Tepung Labu Kuning. Jurnal Aplikasi Teknologi Pangan. 3(4):135-140.

Usha R, Lakshmi M, Ranjani M. 2010. Nutritional, sensory and physical analysis of pumpkin flour incorporated into weaning mix. Mal J Nutr.16(3):379-387.

Viguiliouk E. 2015. Effects of replacing animal protein with plant protein on glycemic control in individuals with diabetes [Thesis]. Toronto: Department of Nutritional Sciences, University of Toronto.

Wu HW, Fang J, Tang LY, Lu P, Xu HY, Zhao Y, Li DF, Zhang Y, Fu MH, Yang HJ. 2014. Quality Evaluation of Astragali Radix based on DPPH Radical Scavenging Activity and Chemical Analysis. Chinese Herbal Medicines 6(4):282-289. doi:10.1016/ S1674-6384(14)60043-5.

Yuni S, Madanijah S, Setiawan B, Marliyati SA. 2016. Pengembangan produk yang berpotensi sebagai minuman fungsional untuk penderita prahipertensi. J Gizi Pangan 11(2):135-142.

Zhao XJ, Chen YL, Fu B, Zhang W, Liu Z, Zhuo H. 2015. Intervention of pumpkin seed oil on metabolic disease revealed by metabonomics and transcript profile. J Sci Food Agric 97(4):1158-1163. doi:10.1002/ jsfa. 7842 . 